\title{
IVC tumoural thrombosis: an unusual complication of testicular tumour
}

\author{
Sunny Goel, Ashok Kumar Gupta, Apul Goel, Ruchir Aeron
}

Department of Urology, King George's Medical University, Lucknow, India

Correspondence to Dr Sunny Goel, drsunnygoel09@ gmail.com

Accepted 8 June 2017
CrossMark

To cite: Goel S, Gupta AK, Goel A, et al. BMJ Case Rep Published Online First: [please include Day Month Year]. doi:10.1136/bcr-2017220677

\section{DESCRIPTION}

A 30-year-old man presented with right scrotal mass and bilateral leg oedema for the last 3 months. CT scan showed a heterogeneously enhancing lesion in the right testis with retroperitoneal and mediastinal lymph node (LN) mass with enhancing tumorous thrombus filling the common iliac veins and inferior vena cava (IVC) up to the infrahepatic region with pulmonary metastases (figure 1). The preoperative tumour markers including lactate dehydrogenase, alpha-fetoprotein and human chorionic gonadotropin were $2270 \mathrm{U} / \mathrm{L}, 28214 \mathrm{ng} / \mathrm{mL}$ and 6253 $\mathrm{mIU} / \mathrm{mL}$, respectively. High inguinal orchidectomy was carried out which revealed mixed germ cell tumour (GCT) (pT3N3M1aS3, poor risk as per International Germ Cell Cancer Collaborative Group). Chemotherapy including four cycles of VIP (etoposide, ifosfamide and cisplatin) with anticoagulation was started in the immediate postoperative period. Standard BEP (bleomycin, etoposide and cisplatin) $\times$ four regimen could not be given because of poor pulmonary function. Postchemotherapy CT scan after 4 weeks revealed complete resolution of IVC thrombus with small residual retroperitoneal and mediastinal lymphadenopathy (figure 2). The tumour markers also normalised. The patient was kept under follow-up for residual mass as he refused postchemotherapy surgical resection.

GCT has propensity for lymphatic and haematogenous spread, but IVC tumour thrombosis is rare. Hassan et $a l^{1}$ described few cases

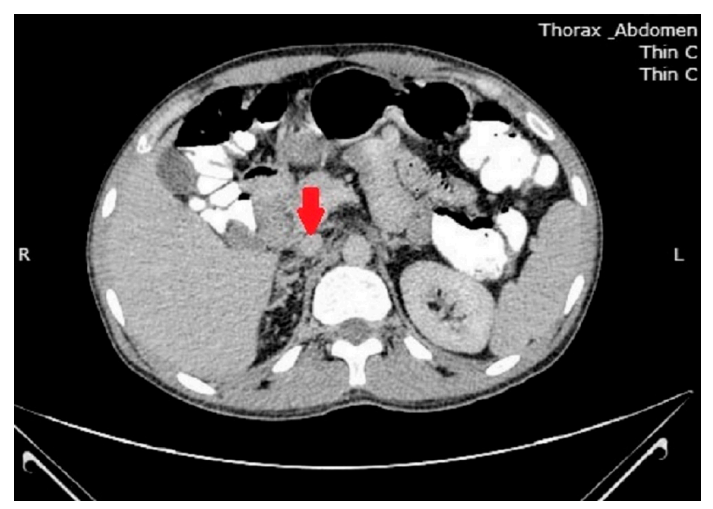

Figure 2 Postchemotherapy contrast-enhanced CT scan-complete resolution of inferior vena cava tumour thrombosis (arrow) after four cycles of VIP.

of GCT with IVC thrombosis and stressed that high index of suspicion is needed in right-sided testicular tumours associated with retroperitoneal $\mathrm{LN}$ masses $>5 \mathrm{~cm}$. IVC thrombosis in our case completely regressed after chemotherapy, although Dusaud et $a l^{2}$ described rare regression of IVC thrombosis with chemotherapy alone, with patients ultimately requiring thrombectomy.

Contributors SG, concept, design, supervision, processing, writing manuscript and critical analysis. AKG, concept, design, supervision, processing, writing manuscript and critical analysis. $A G$, supervision, processing, writing manuscript and critical analysis. RA, concept, supervision, writing manuscript and critical analysis.

Competing interests None declared.

Patient consent Obtained.

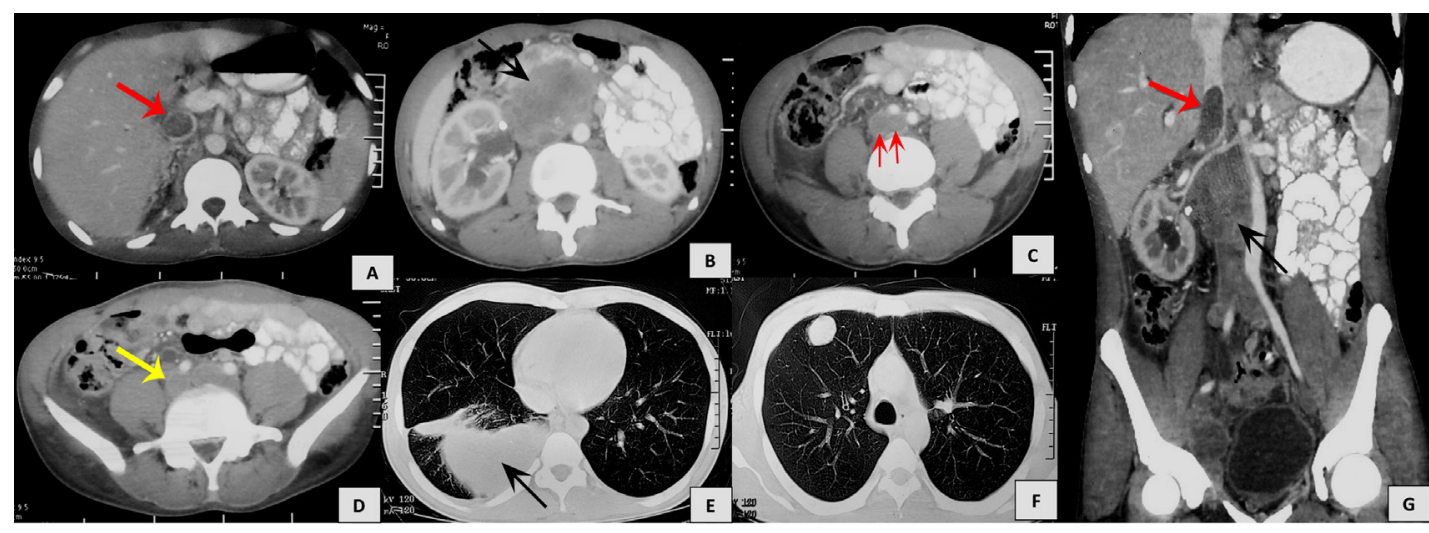

Figure 1 Contrast-enhanced CT scan. (A) Infrahepatic inferior vena cava (IVC) tumorous thrombosis (arrow) filling almost whole of the circumference. (B) Large heterogeneous enhancing retroperitoneal lymph nodal mass (arrow). (C) Bifurcation of IVC showing tumorous thrombosis (multiple arrows). (D) Tumour thrombosis extending up to bilateral common iliac veins (arrow), (E) showing hypodense opacity (arrow) in right lung lower lobe (collapse/consolidation) with minimal right pleural effusion, (F) showing pulmonary metastases. (G) Sagittal section showing IVC thrombosis (coloured arrow) with retroperitoneal lymph node mass (black arrow). 


\section{Learning points}

- Germ cell tumour has propensity for lymphatic and haematogenous spread, but inferior vena cava tumour thrombosis is rare.

- A high index of suspicion must accompany the evaluation of a patient with a right-sided primary testicular tumour and a paracaval abdominal mass measuring $>5 \mathrm{~cm}$ in maximum transverse dimension.
Provenance and peer review Not commissioned; externally peer reviewed.

(C) BMJ Publishing Group Ltd (unless otherwise stated in the text of the article) 2017. All rights reserved. No commercial use is permitted unless otherwise expressly granted.

\section{REFERENCES}

1 Hassan B, Tung K, Weeks R, et al. The management of inferior vena cava obstruction complicating metastatic germ cell tumors. Cancer 1999;85:912-8.

2 Dusaud M, Bayoud Y, Desfemmes FR, et al. Unusual presentation of testicular cancer with tumor thrombus extending to the inferior vena cava. Case Rep Urol 2015:2015:1-3

Copyright 2017 BMJ Publishing Group. All rights reserved. For permission to reuse any of this content visit http://group.bmj.com/group/rights-licensing/permissions.

BMJ Case Report Fellows may re-use this article for personal use and teaching without any further permission.

Become a Fellow of BMJ Case Reports today and you can:

- Submit as many cases as you like

- Enjoy fast sympathetic peer review and rapid publication of accepted articles

- Access all the published articles

- Re-use any of the published material for personal use and teaching without further permission

For information on Institutional Fellowships contact consortiasales@bmjgroup.com

Visit casereports.bmj.com for more articles like this and to become a Fellow 